\title{
KAJIAN YURIDIS AKTA PEJABAT PEMBUAT AKTA TANAH SEBAGAI AKTA AUTENTIK DALAM PERALIHAN HAK ATAS TANAH
}

\section{JURIDICAL STUDY OFFICIAL MAKERS AS AUTENTIC ACTS IN THE TRANSITION OF LAND RIGHTS}

\author{
Sulthon Akim \\ Universitas Muhammadiyah Jember \\ Email: sulthonakim@unmuhjember.ac.id
}

\begin{abstract}
ABSTRAK
Akta autentik adalah suatu akta yang dibuat oleh dan dihadapan seorang pejabat umum yang menurut undang-undang ditugaskan untuk membuat surat-surat akta tersebut. Sebuah akta dinyatakan sebagai akta autentik apabila memenuhi unsur-unsur yang bersifat kumulatif sebagaimana ditentukan Pasal 1868 KUH Perdata yaitu: bentuk akta yang ditentukan oleh undang-undang, akta itu dibuat oleh dan dihadapan pegawaipegawai umum yang berkuasa dan akta itu dibuat ditempat dimana akta dibuatnya. Akta autentik yang dibuat oleh PPAT dalam peralihan hak atas tanah bentuknya tidak ditentukan undang-undang tetapi ditentukan Peraturan Pemerintah dan Peraturan Menteri Negara/Kepala BPN. Berdasarkan adanya perbedaan ini maka akta autentik yang dibuat oleh PPAT apakah bisa dinyatakan sebagai akta autentik yang mempunyai kekuatan hukum yang sempurna (volledig bewijs).

Kata Kunci : Akta Autentik, Akta Peralihan Hak atas Tanah, Pejabat Pembuat Akta Tanah

ABSTRACT

An authentic deed is a deed made by and in the presence of a public official who, by law, is assigned to make such deeds. A deed is expressed as an authentic deed if it meets the cumulative elements as stipulated in Article 1868 Civil Code namely: the form of deed determined by law, the deed is made by and before the ruling public officials and the deed is made in place of the deed he made. Authentic deeds made by PPAT in the transfer of land rights are not specified by law but determined by Government Regulation and Regulation of State Minister / Head of BPN. Based on this discrepancy, the authentic deeds made by PPAT can be expressed as authentic deeds that have perfect legal force (volledig bewijs).
\end{abstract}

Keywords: Authentic Deed, Land Acquisition Deed, Land Acquisition Official

\section{PENDAHULUAN}

Awal keberadaan institusi Pejabat Pembuat Akta Tanah telah ada sejak tahun 1961 berdasarkan Peraturan Pemerintah Republik Indonesia No.10 Tahun 1961 tentang pendaftaran tanah. Pada awal kelahirannya Pejabat Pembuat Akta Tanah tidak dikategorikan sebagai pejabat umum, tetapi sebagai pejabat pembuat akta tanah saja. Pejabat Pembuat Akta Tanah dikategorikan sebagai pejabat umum hal ini dinyatakan dalam Pasal 1 Angka 4 Undang-Undang No.4 Tahun 1996 tentang hak tanggungan atas tanah beserta benda-benda yang berkaitan dengan tanah yang menyatakan Pejabat Pembuat Akta Tanah yang selanjutnya disebut PPAT adalah pejabat umum yang diberi wewenang untuk membuat akta pemindahan hak atas tanah, akta pembebanan atas tanah, dan akta pemberian kuasa membebankan hak tanggungan menurut peraturan perundangundangan yang berlaku. Adapun pejabat yang diberi wewenang untuk membuat akta dalam peralihan hak atas tanah adalah Pejabat Pembuat Akta Tanah (PPAT), Pejabat 
Pembuat Akta Ikrar Wakaf (PPAIW), Panitia Ajudikasi, Notaris yang sudah diangkat menjadi PPAT, Pejabat Kantor Lelang.

Selanjutnya secara khusus keberadaan Pejabat Pembuat Akta Tanah diatur dalam Pasal 1 Ayat (1) PP No.37 Tahun 1998 tentang peraturan jabatan pembuat akta tanah (PJPAT) yang menyebutkan bahwa : "PPAT adalah pejabat umum yang diberi kewenangan untuk membuat akta-akta autentik mengenai perbuatan hukum tertentu mengenai hak atas tanah atau hak milik atas satuan rumah susun".

Untuk mengetahui batasan perbuatan hukum tertentu yang berkaitan dengan pembuatan akta yang menjadi kewenangan PPAT sebagaimana disebutkan dalam Pasal 95 Peraturan Menteri Negara/Kepala BPN No.3 Tahun 1997 jo. Pasal 2 Ayat (2) PP No.37 Tahun 1998 bahwa perbuatan hukum tersebut mengenai : jual beli, tukar menukar, hibah, pemasukan ke dalam perusahaan (inbreng), pembagian hak bersama, pemberian hak guna bangunan/hak pakai atas hak milik, pemberian hak tanggungan, dan surat kuasa membebankan hak tanggungan. Berdasarkan ketentuan ini PPAT berwenang menciptakan, membuat, dan mengerjakan akta; yaitu melakukan dan membuat sendiri akta dengan jenis dan bentuknya mengacu pada Pasal 95 Peraturan Menteri Negara Agraria/Kep.BPN No.3 Tahun 1997 jo. Pasal 2 Ayata (2) PP No.37 Tahun 1998. Disamping itu PPAT mempunyai tugas sebagai recording of deed confeyance (perekam dari perbuatan) sehingga wajib mengkonstatir kehendak para pihak yang telah mencapai suatu kesepakatan diantara mereka, dan mengesahkan suatu perbuatan hukum diantara para pihak yang bersubstansi mengesahkan tanda tangan pihak-pihak yang mengadakan perbuatan hukum dan menjamin kepastian tanggal pembuatan akta.

Dalam keterkaitan peralihan hak atas tanah fungsi akta PPAT adalah sebagai bukti telah diadakan perbuatan hukum mengenai hak atas tanah atau hak milik satuan rumah susun, dan akta PPAT akan dijadikan dasar bagi pendaftaran perubahan data pendafataran tanah ke kantor pertanahan kabupaten/kota. Pendaftaran perubahan data ini bisa dilaksanakan bilamana 2 syarat terpenuhi yaitu; syarat materiil dan syarat formil. Dalam ketentuan syarat materiil ditegaskan bahwa pemegang hak atas tanah atau hak milik atas satuan rumah susun berhak dan berwenang menjual hak atas tanah atau hak milik atas satuan rumah susun, dan pembeli harus memenuhi syarat sebagai pembeli hak dari hak atas tanah atau hak milik atas satuan rumah susun yang menjadi objek jual beli. Dalam ketentuan syarat formil ditegaskan bahwa dalam rangka pendaftaran pemindahan hak jual beli hak atas tanah atau hak milik atas satuan rumah susun harus dibuktikan dengan akta yang dibuat oleh dan dihadapan PPAT. Syarat jual beli harus dibuktikan dengan akta yang ditegaskan dalam Pasal 37 Ayat (1) PP No.24 Tahun 1997 yaitu "Peralihan hak atas tanah dan hak milik atas satuan rumah susun melalui jual beli, tukar menukar, hibah, pemasukan dalam perusahaan dan perbuatan hukum pemindahan hak lainnya, kecuali pemindahan hak melalui lelang hanya dapat didaftarkan jika dibuktikan dengan akta yang dibuat oleh PPAT yang berwenang menurut ketentuan peraturan perundang-undangan yang berlaku".

Dengan telah dibuatnya akta jual beli oleh PPAT maka pada saat itu telah terjadi pemindahan hak atas tanah atau hak milik atas satuan rumah susun dari pemegang haknya sebagai penjual kepada pihak lain sebagai pembeli. Agar pihak ketiga mengetahuinya maka jual beli harus didaftarkan ke kantor pertanahan kabupaten/kota setempat maka terpenuhilah asas publisitas dalam pendafataran tanah yaitu; setiap orang dapat mengetahui data fisik berupa letak, ukuran, batas-batas tanah, dan data yuridis 
berupa subjek hak, status hak, dan pemindahan hak atas tanah atau hak milik atas satuan rumah susun yang bersangkutan ke kantor pertanahan kabupaten/kota.

Akta PPAT menurut Pasal 1 Angka 4 PP No.37 Tahun 1998 jo. Pasal 1 Angka 4 Peraturan Kepala BPN RI No.1 Tahun 2006 : "adalah akta yang dibuat oleh PPAT sebagai bukti dilaksanakannya perbuatan hukum tertentu mengenai hak atas tanah atau hak milik atas satuan rumah susun". Berdasarkan Pasal 3 Ayat (1) PP No.37 Tahun 1998 jo. Pasal 3 Ayat (1) Peraturan Kepala BPN No.1 Tahun 2006 bahwa : akta yang dibuat oleh PPAT adalah akta autentik. Menurut undang-undang suatu akta autentik mempunyai kekuatan hukum yang sempurna (folledig bewijs) artinya apabila suatu pihak mengajukan suatu akta autentik hakim harus menerimanya dan menganggap bahwa apa yang dituliskan dalam akta itu sungguh-sungguh terjadi sehingga hakim tidak boleh memerintahkan pembuktian lagi.

Akta PPAT tidak ditentukan oleh undang-undang melainkan ditentukan oleh Peraturan Pemerintah dan Peraturan Menteri Negara Agraia/Kepala BPN yaitu :

1. Pasal 38 Ayat (2) PP No.24 Tahun 1997 yang menyatakan bahwa bentuk isi dan cara pembuatan akta-akta PPAT diatur oleh Menteri Negara Agraria/Kepala BPN;

2. Pasal 21 PP No.37 Tahun 1998 menyatakan bahwa akta PPAT dibuat dengan bentuk ditetapkan oleh Menteri Negara Agraria/Kepala BPN;

3. Pasal 95 dan Pasal 96 Peraturan Menteri Negara Agraria/Kepala BPN No.3 Tahun 1997 menetapkan bahwa macam-macam dan bentuk akta yang dibuat oleh PPAT.

Akta adalah tulisan yang sengaja dibuat untuk dijadikan bukti tentang suatu peristiwa dan ditandatangani. Akta autentik dalam hubungannya dengan kontrak adalah kontrak yang dibuat oleh Notaris sebagai pejabat umum. Akta autentik menurut Pasal 1868 KUHPerdata "adalah suatu akta yang di dalam bentuk yang ditentukan oleh undang-undang dibuat oleh atau dihadapan pegawai umum yang berkuasa untuk itu ditempat dimana akta dibuatnya". Suatu akta dinyatakan sebagai akta autentik apabila memenuhi unsur-unsur yang bersifat komulatif sebagaimana ditentukan oleh Pasal 1868 KUHPerdata yaitu :

1. Bentuk akta ditentukan oleh undang-undang;

2. Akta dibuat oleh dan dihadapan pegawai umum yang berkuasa;

3. Akta itu dibuat ditempat dimana akta dibuatnya.

Akta yang dibuat oleh atau dihadapan pejabat umum dalam bentuk yang sudah ditentukan undang-undang harus diartikan sebagaimana yang tersebut dalam UndangUndang No.12 Tahun 2011 tentang Pembentukan Peraturan Perundang-Undangan Pasal 1 Angka 2 undang-undang ini menegaskan bahwa : peraturan perundang-undangan adalah peraturan tertulis yang memuat norma hukum yang mengikat secara umum dan dibentuk atau ditetapkan oleh lembaga negara atau pejabat yang berwenang melalui prosedur yang ditetapkan dalam peraturan perundang-undangan. Pasal 1 Angka 3 undang-undang ini juga menegaskan bahwa : undang-undang adalah peraturan perundang-undangan yang dibentuk oleh DPR dengan persetujuan bersama Presiden. Adapun kekuatan hukum peraturan perundang-undangan menurut Pasal 7 Ayat 2 undang-undang ini ditentukan sesuai dengan hierarki beserta jenisnya.

Berdasarkan uraian ini Penulis tertarik untuk mengkaji keberadaan akta peralihan hak atas tanah yang dibuat oleh PPAT sebagai akta autentik yang mempunyai kekuatan pembuktian sempurna, dalam telaah Pasal 1868 KUHPerdata serta hierarki Perauturan 
Perundang-Undangan yang diatur dalam Undang-Undang No.12 Tahun 2011 tentang Pembentukan Peraturan Perundang-Undangan dimana ketentuan ini diberlakukan kepada Notaris selaku pejabat umum dalam membuat akta autentik.

Berdasarkan uraian pada latar belakang tersebut dirumuskan permasalahan yaitu: Bagaimanakah kedudukan hukum akta autentik yang dibuat oleh dan dihadapan Pejabat Pembuat Akta Tanah (PPAT) dalam peralihan hak atas tanah?

\section{HASIL PENELITIAN DAN PEMBAHASAN}

Pasal 1 Ayat (4) Peraturan Pemerintah No.37 Tahun 1998 menyebutkan : "akta PPAT adalah akta yang dibuat oleh PPAT sebagai bukti telah dilaksanakan perbuatan hukum tertentu mengenai hak atas tanah atau hak milik atas satuan rumah susun". Akta PPAT merupakan salah satu sumber utama dalam rangka pemeliharaan pendaftaran tanah di Indonesia. Setiap perjanjian yang bermaksud memindahkan hak atas tanah, memberikan suatu hak baru atas tanah, menggadaikan tanah, atau meminjam uang dengan hak atas tanah sebagai tanggungan, harus dibuktikan dengan suatu akta yang dibuat oleh dan dihadapan Pejabat Pembuat Akta Tanah.

Menurut Pasal 37 Ayat (1) Peraturan Pemerintah No.24 Tahun 1997 bahwa : "peralihan hak atas tanah dan hak milik atas satuan rumah susun melalui jual beli, tukar menukar, hibah, pemasukan data perusahaan dan perbuatan hukum pemindahan hak lainnya, kecuali pemindahan hak melalui lelang hanya dapat didaftarkan jika dibuktikan dengan akta yang dibuat oleh PPAT yang berwenang menurut ketentuan peraturan perundang-undangan yang berlaku".

PPAT sebagai pejabat umum, akta yang dibuatnya diberi kedudukan sebagai akta autentik, yaitu akta yang dibuat untuk membuktikan adanya perbuatan hukum tertentu yang mengakibatkan terjadinya peralihan hak atas tanah dan bangunan. PPAT mempunyai peranan besar dalam peralihan hak atas tanah karena memiliki tugas membantu kepala kantor pertanahan dalam rangka melaksanakan kegiatan pendaftaran tanah dengan membuat akta sebagai bukti telah dilakukannya perbuatan hukum tertentu mengenai hak atas tanah yang merupakan akta autentik. Sebagai akta autentik akta PPAT haruslah memenuhi tata cara pembuatan akta PPAT sebagaimana yang ditentukan oleh undang-undang dan peraturan-peraturan lainnya. Pembuatan akta yang tidak sesuai dengan tata cara pembuatan akta PPAT dapat membuat suatu akta batal demi hukum dan mengakibatkan kerugian bagi salah satu pihak dalam akta tersebut.

Pejabat Pembuat Akta Tanah mempunyai peran yang penting dalam pendaftaran tanah, yaitu membantu Kepala Kantor Pertanahan Kabupaten/Kota untuk melaksanakan kegiatan-kegiatan tertentu dalam pendaftaran tanah. Kata "dibantu" dalam Pasal 6 Ayat (2) PP No.24 Tahun 1997 disini tidak berarti bahwa PPAT merupakan bawahan dari kantor pertanahan kabupaten atau kota yang dapat diperintah olehnya, akan tetapi PPAT mempunyai kemandirian dalam melaksanakan tugas dan wewenangnya.

Tugas pokok PPAT dalam membantu pelaksanaan pendaftaran tanah oleh Kepala Kantor Pertanahan Kabupaten/Kota ditetapkan dalam Pasal 2 PP No.37 Tahun 1998, yaitu : melaksanakan sebagian pendaftaran tanah dengan membuat akta sebagai bukti telah dilakukan perbuatan hukum tertentu mengenai hak atas tanah atau hak milik atas satuan rumah susun yang akan dijadikan dasar bagi pendaftaran perubahan data pendaftaran tanah yang diakibatkan perbuatan hukum tadi. Adapun perbuatan hukum yang dimaksud adalah : jual beli, tukar menukar, hibah, pemasukan kedalam perusahaan (inbreng), pembagian hak bersama, pemberian hak guna bangunan/hak pakai atas tanah 
hak milik, pemberian hak tanggungan dan pemberian hak kuasa membebankan hak tanggungan.

Pejabat Pembuat Akta Tanah dan Pejabat Pembuat Akta Tanah Sementara hanya berwenang membuat akta autentik terhadap perbuatan mengenai hak atas tanah atau hak milik atas satuan rumah susun yang terletak dalam daerah kerjanya. Daerah kerja PPAT adalah satu wilayah kerja kantor pertanahan kabupaten/kota, sedangkan daerah kerja PPAT Sementara meliputi wilayah kerja sebagai pejabat pemerintah yang menjadi dasar penunjukan.

Dalam Pasal 1 Angka 4 Undang-Undang No.4 Tahun 1996 menyatakan : "Pejabat Pembuat Akta Tanah adalah pejabat umum yang diberi wewenang untuk membuat akta pemindahan hak atas tanah, akta pembebanan hak tanggungan menurut perundang-undangan yang berlaku". Istilah pejabat umum bagi pejabat pembuat akta tanah baru ada pada Undang-Undang No.4 Tahun 1996, namun dalam undang-undang ini maupun pada peraturan perundang-undangan yang lain tidak memberikan pengertian apa yang dimaksud pejabat umum.

Menurut Boedi Harsono, yang dimaksud pejabat umum adalah seorang yang diangkat oleh pemerintah dengan tugas kewenangan memberikan pelayanan di bidang tertentu. ${ }^{1}$

Sejalan dengan Boedi Harsono, Sri Winarsih menyatakan bahwa pengertian pejabat umum mempunyai karakter yuridis, yaitu selalu dalam rangka hukum publik. Sifat publiknya dapat dilihat dari pengangkatan, pemberhentian, dan kewenangan pejabat pembuat akta tanah. ${ }^{2}$ Pejabat Pembuat Akta Tanah diangkat dan diberhentikan oleh Kepala Badan Pertanahan Nasional Republik Indonesia, tugasnya adalah membantu kepala kantor pertanahan kabupaten/kota dalam melaksanakan sebagian kegiatan pendaftaran tanah, dan kewenangannya adalah membuat akta atas perbuatan hukum tertentu mengenai hak atas tanah atau hak milik atas satuan rumah susun.

Menurut ketentuan peraturan perundang-undangan yang berlaku, Pasal 3 Ayat (1) PP No.37 Tahun 1998 jo. Pasal 3 Ayat (1) Peraturan Kepala BPN No.1 Tahun 2006 menegaskan bahwa akta yang dibuat oleh Pejabat Pembuat Akta Tanah adalah akta autentik. Pejabat Pembuat Akta Tanah yang berwenang membuat akta jual beli hak atas tanah atau hak milik atas satuan rumah susun berdasarkan Pasal 1 Angka 1 PP No.37 Tahun 1998 tentang peraturan jabatan pejabat pembuat akta tanah adalah Pejabat Pembuat Akta Tanah sebagai pejabat umum yang diberikan kewenangan untuk membuat akta-akta autentik mengenai perbuatan-perbuatan hukum tertentu mengenai hak atas tanah atau hak milik atas satuan rumah susun. Disamping itu menurut Pasal 1 Angka 2 PP No.37 Tahun 1998 yang berwenang membuat akta jual beli adalah Pejabat Pembuat Akta Tanah Sementara yang ditunjuk karena jabatannya (Kepala Kecamatan). Dengan telah dibuatnya akta jual beli oleh Pejabat Pembuat Akta Tanah maka pada saat itu telah terjadi pemindahan hak atas tanah.

Menurut Pasal 1 Angka 4 PP No.37 Tahun 1998 jo. Pasal 1 Angka 4 Peraturan Kepala BPN No.1 Tahun 2006 akta PPAT adalah akta yang dibuat oleh PPAT sebagai bukti dilaksanakannya perbuatan hukum tertentu mengenai hak atas tanah atau hak milik atas satuan rumah susun.

Menurut Pasal 39 Ayat (1) PP No.24 Tahun 1997 PPAT menolak membuat akta jual beli jika :

\footnotetext{
${ }^{1}$ Boedi Harsono. Op Cit, hlm. 11

${ }^{2}$ Sri Winarsih. Op Cit, hlm. 186
} 
1. Mengait bidang tanah yang sudah terdaftar kepadanya tidak disampaikan sertipikat asli hak atas tanah yang bersangkutan atau sertipikat yang diserahkan tidak sesuai dengan daftar-daftar yang ada di kantor pertanahan kabupaten/kota.

2. Salah satu/para pihak yang akan melakukan jual beli atau saksinya tidak berhak atau memenuhi syarat untuk bertindak dalam jual beli.

3. Salah satu atau para pihak bertindak atas dasar surat kuasa mutlak yang pada hakikatnya berisikan perbuatan hukum pemindahan hak.

4. Untuk jual beli yang akan dilakukan belum diperoleh izin pejabat atau instansi yang berwenang.

5. Objek jual beli yang sedang dalam sengketa mengenai data fisik dan data yuridis.

6. Tidak dipenuhi syarat lain atau dilanggar larangan yang ditentukan dalam peraturan perundangan yang berlaku.

Penolakan untuk melakukan jual beli tersebut diberitahukan oleh PPAT secara tertulis kepada pihak-pihak yang bersangkutan beserta alasannya.

Menurut Pasal 45 Ayat (2) PP No.24 Tahun 1997 Kepala Kantor Pertanahan menolak untuk melakukan pendaftaran peralihan atau pembebanan hak jika salah satu syarat tidak dipenuhi diantaranya syarat tersebut yaitu : perbuatan hukum sebagaimana dimaksud dalam Pasal 37 Ayat (1) dalam peraturan ini tidak dibuktikan dengan akta PPAT atau kutipan risalah lelang sebagaimana yang dimaksud dalam Pasal 41, kecuali dalam keadaan tertentu sebagaimana dimaksud Pasal 37 Ayat (2) dalam peraturan ini.

Pasal 3 Ayat (1) PP No 31 Tahun 1998 jo. Pasal 3 Ayat (1) Peraturan Kepala Badan Pertanahan Nasional No.1 Tahun 2006 menegaskan bahwa akta yang dibuat oleh PPAT adalah akta autentik. Dalam kedua peraturan ini tidak dijelaskan apa yang dimaksud dengan akta autentik. Akta autentik menurut Pasal 1868 KUH Perdata, adalah suatu akta di dalam bentuk yang ditentukan oleh undang-undang, dibuat oleh dan dihadapan pegawai-pegawai umum yang berkuasa untuk itu dimana akta dibuatnya. ${ }^{3}$

Suatu akta dinyatakan sebagai akta autentik apabila memenuhi unsur-unsur yang bersifat komulatif sebagaimana ditentukan oleh Pasal 1868 KUH Perdata, yaitu :

1. Bentuk akta ditentukan oleh undang-undang

2. Akta dibuat oleh dan dihadapan pegawai-pegawai umum yang berkuasa

3. Akta dibuat dimana akta dibuatnya

Pendapat yang sama tentang unsur-unsur akta autentik dikemukakan oleh Wawan Setiawan, yaitu :

1. Bentuk akta harus ditentukan oleh undang-undang artinya tidak boleh ditentukan oleh perangkat peraturan perundang-undangan di bawah undang-undang

2. Dibuat oleh dan dihadapan pejabat umum

3. Akta tersebut dibuat oleh atau dihadapan pejabat umum dalam wilayah jabatan sesuai dengan kewenangannya ${ }^{4}$

Berdasarkan ketentuan Pasal 1868 KUH Perdata dapat disimpulkan bahwa, suatu akta dinyatakan sebagai akta autentik apabila mempunyai 3 unsur yang bersifat komulatif, yaitu :

1. Bentuk akta ditentukan oleh UU

2. Akta dibuat oleh dan dihadapan pejabat umum yang diberi kewenangan untuk membuat akta

\footnotetext{
${ }^{3}$ R. Soebekti dan R. Tjitro Sudibyo. Kitab Undang-Undang Hukum Perdata. (Jakarta : Pradnya Paramita, 1985), hlm. 419

4 Wawan Setiawan. Kedudukan dan Keberadaan Pejabat Umum serta PPAT dibandingkan dengan Kedudukan Pejabat Tata Usaha Negara Menurut Sistem Hukum Nasional. (Surabaya : Makalah, 1 Juni 1996), hlm. 12
} 
3. Akta dibuat oleh pejabat umum dalam daerah (wilayah) kerjanya Akta PPAT tidak ditentukan oleh undang-undang melainkan ditentukan oleh PP dan Peraturan Menteri Negara Agraria/ Kepala BPN, yaitu :

1. Pasal 38 Ayat (2) PP No. 24 Tahun 1997 menyatakan bahwa bentuk, isi dan cara pembuatan akta-akta PPAT diaturan oleh Peraturan Menteri Negara Agraria. Kepala BPN

2. Pasal 21 PP No. 37 Tahun 1998 menyatakan bahwa akta PPAT dibuat dengan bentuk yang ditetapkan oleh Menteri Negara Agraria/ Kepala BPN

3. Pasal 95 dan Pasal 96 Peraturan Menteri Negara Agraria/ Kepala BPN No.3 Tahun 1997 menetapkan bahwa macam dan bentuk akta yang dibuat oleh PPAT Berdasarkan ketiga peraturan ini menunjukkan bahwa akta PPAT bentuknya tidak ditentukan oleh undang-undang melainkan ditetapkan oleh PP dan Peraturan Menteri, meskipun akta PPAT tersebut bentuknya baku dan dibuat oleh PPAT sebagai pejabat umum. Untuk lebih konkritnya dalam menelaah kedudukan hukum akta autentik yang dibuat oleh PPAT penulis komparasikan dengan akta autentik yang dibuat oleh notaris yang telah dibuat berdasarkan kententuan Undang-Undang No.2 Tahun 20014 tentang Perubahan atas Undang-Undang No.30 Tahun 2004 tentang Jabatan Notaris serta Undang-Undang No.12 Tahun 2011 tentang Pembentukan Peraturan PerundangUndangan.

Adapun syarat-syarat yang harus dipenuhi untuk dapat dikategorikan sebagai akta autentik dalam komparasi ini, diuraikan sebagai berikut :

1. Akta itu harus dibuat dalam bentuk yang ditentukan oleh undang-undang

Akta yang dibuat oleh atau dihadapan pejabat umum dalam bentuk yang sudah ditentukan undang-undang harus diartikan sebagaimana yang tersebut dalam Undang-Undang No.12 Tahun 2011 tentang Pembentukan Peraturan Perundang-Undangan, Pasal 1 Angka 2 yang menegaskan bahwa : "peraturan perundang-undangan adalah peraturan tertulis yang memuat norma hukum yang mengikat secara umum dan dibentuk atau ditetapkan oleh lembaga negara atau pejabat yang berwenang melalui prosedur yang ditetapkan dalam peraturan perundang-undangan “.

Dalam Pasal 1 angka 3 undang-undang ini menegaskan bahwa : "undangundang adalah peraturan perundang-undangan yang dibentuk oleh DPR dengan persetujuan bersama Presiden".

Berdasarkan Pasal 7 Ayat (1) dan (2) Undang-Undang No.12 Tahun 2011 tentang Pembentukan Peraturan Perundang-Undangan dinyatakan bahwa jenis hierarki peraturan perundang-undangan terdiri atas :

1. Undang-Undang Dasar Negara Republik Indonesia Tahun 1945

2. Ketetapan MPR

3. Undang-Undang/Peraturan Pemerintah Pengganti Undang-Undang

4. Peraturan Pemerintah

5. Peraturan Presiden

6. Peraturan Daerah Provinsi; dan

7. Peraturan Daerah Kabupaten/Kota

Berdasarkan ketentuan Pasal 7 Ayat (2) undang-undang ini kekuatan hukum peraturan perundang-undangan sesuai dengan hierarki yang telah ditetapkan sebagaimana tertuang dalam Pasal 7 Ayat (1) undang-undang ini.

Pengaturan pertama kali notaris Indonesia berdasarkan instruktie foor de notarissen residerende in nederlands indie dengan stbl.No 11, tanggal 7 Maret 
1822, kemudian dengan reglement op het notaris ambt in Indonesie (stbl. 1860 : 3), dan reglement ini berasal dari wet op het notarisambt (1842). Selanjutnya reglement tersebut diterjemahkan menjadi peraturan jabatan notaris. Meskipun notaris di Indonesia diatur dalam bentuk reglement, hal tersebut tidak dipermasalahkan karena sejak lembaga Notaris lahir di Indonesia, pengaturannya tidak lebih dari bentuk reglement dan secara kelembagaan dengan UndangUndang No.33 Tahun 1954 yang tidak mengatur mengenai bentuk akta. Setelah lahirnya undang-undang jabatan notaris, keberadaan akta notaris mendapat pengukuhan karena bentuknya ditentukan oleh undang-undang, dalam hal ini dalam Pasal 38 undang-undang jabatan Notaris. Akta PPAT sampai dengan saat ini belum diatur keberadaannya dalam bentuk undang-undang tetapi dalam PP atau Peraturan Menteri.

2. Pejabat umum oleh - atau dihadapan siapa akta itu dibuat, harus memenuhi wewenang untuk membuat akta itu.

Kewenangan Notaris dan PPAT meliputi 4 hal, yaitu :

a. Notaris harus berwenang sepanjang menyangkut akta yang harus dibuat itu.

Wewenang Notaris dan PPAT dalam pembuatan akta autentik sepanjang tidak dikecualikan kepada atau pejabat lain atau notaris juga berwenang membuatnya. Disamping dapat dibuat oleh pihak atau pejabat lain, juga mengandung makna bahwa wewenang notaris dalam membuat akta autentik mempunyai wewenang yang umum, sedangkan pihak lainnya mempunyai wewenang yang terbatas. Misalnya, PPAT mempunyai wewenang terbatas, yaitu hanya membuat 8 jenis akta.

b. Notaris harus berwenang sepanjang mengenai orang untuk kepentingan siapa akta itu dibuat.

Pejabat umum-Notaris dan PPAT berwenang sepanjang mengenai orang untuk kepentingan siapa akta itu dibuat. Mengenai orang dan untuk siapa akta dibuat harus ada keterkaitan yang jelas. Misalnya, jika akan dibuat akta pengikatan jual beli yang diikuti dengan akta kuasa untuk menjual, pihak yang akan menjual mempunyai wewenang untuk menjualnya kepada siapapun. Untuk mengetahui ada keterkaitan semacam itu, sudah tentu notaris akan melihat (asli surat) dan meminta fotokopi atas identitas dan bukti kepemilikannya. Salah satu tanda bukti yang sering diminta oleh notaris dalam pembuatan akta notaris, yaitu kartu tanda tertentu (KTP) dan sertipikat tanah sebagai bukti kepemilikannya. Ada kemungkinan orang yang namanya tersebut dalam KTP dan sertipikat bukan orang yang sama, artinya pemilik sertipikat bukan orang yang sesuai dengan KTP. Hal ini bisa terjadi (di Indonesia) karena banyak kesamaan nama dan mudahnya membuat KTP serta dalam sertipikat hanya tertulis nama pemegang hak, tanpa ada penyebutan identitas lain. Dalam kejadian seperti ini, bagi Notaris tidak menimbulkan permasalahan apapun tetapi dari segi lain notaris oleh pihak yang berwajib (kepolisian/penyidik) dianggap memberikan kemudahan untuk terjadinya suatu tindak pidana. Berkaitan dengan identitas diri penghadap dan bukti kepemilikannya yang di bawa dan aslinya diperlihatkan ternyata palsu, maka hal ini bukan tanggung jawab notaris melainkan tanggung jawab tersebut diserahkan para pihak yang menghadap.

c. Pejabat umum harus berwenang sepanjang mengenai tempat dimana akta itu dibuat. 
Pejabat umum - Notaris dan PPAT harus berwenang sepanjang mengenai tempat dimana akta itu dibuat. Baik notaris maupun PPAT mempunyai tempat kedudukan dan wilayah kerjanya masing-masing. Misalnya untuk notaris sebagaimana tercantum dalam pasal 18 ayat (1) undang-undang jabatan Notaris menentukan bahwa Notaris harus berkedudukan di daerah kabupaten atau kota. Setiap Notaris sesuai dengan keinginannya mempunyai tempat kedudukan dan wilayah kerjanya masing-masing. Misalnya, untuk Notaris sebagaimana tercantum dalam pasal 18 ayat (1) undang-undang jabatan Notaris menentukan bahwa notaris harus berkedudukan di daerah kabupaten atau kota. Setiap Notaris sesuai dengan keinginannya mempunyai tempat kedudukan dan berkantor di daerah kabupaten/ kota (pasal 19 ayat (1) undang-undang jabatan Notaris). Notaris mempunyai wilayah jabatan meliputi seluruh wilayah propinsi dari tempat kedudukannya (pasal 19 ayat (2) undang-undang jabatan Notaris). Pengertian pasal-pasal tersebut bahwa Notaris dalam menjalankan tugas jabatannya tidak hanya harus berada di tempat kedudukannya karena notaris mempunyai wilayah seluruh propinsi misalnya, Notaris yang berkedudukan di kota Surabaya, maka dapat membuat akta di kabupaten atau kota lain dalam wilayah propinsi jawa timur. Hal ini dapat dijalankan dengan ketentuan :

1. Ketika Notaris menjalan tugas jabatannya (membuat akta) diluar tempat kedudukannya Notaris tersebut harus berada di tempat akta akan dibuat. Sebagi contoh, notaris yang berkedudukan di Surabaya akan membuat akta di Mojokerto, maka Notaris yang bersangkutan harus membuat dan menyelesaikan akta tersebut di Mojokerto.

2. Pada akhir akta harus disebutkan tempat (kota atau kabupaten) pembuatan dan penyelesaian akta.

3. Menjalankan tugas jabatan di luar tempat kedudukan Notaris dalam wilayah jabatan 1 provinsi tidak merupakan suatu keteraturan yang tidak terus menerus (pasal 19 ayat (2) undang-undang jabatan Notaris)

Ketentuan tersebut dalam praktik memberikan peluang pada Notaris untuk menambah dan melintasi batas tempat kedudukan dalam pembuatan akta. Hal tersebut bukan merupakan suatu hal yang dilarang untuk dilakukan karena yang dilarang adalah menjalankan tugas jabatannya diluar wilayah jabatannya atau diluar provinsi (pasal 17 huruf a undang-undang jabatan Notaris). Akan tetapi untuk saling menghormati antar Notaris di kabupaten atau kota lain lebih baik hal seperti itu tidak dilakukan. Berikan penjelasan kepada para pihak dengan membuat akta yang di inginkan utk datang menghadap Notaris di kabupaten atau kota yang bersangkutan. Dalam keadaan tertentu dapat saja dilakukan jika di kabupaten atau kota tersebut tidak ada Notaris.

Adanya ketentuan tersebut bagi Notaris yang mempunyai tempat kedudukan di kota atau kabupaten dan wilayah kerja provinsi, sebenarnya telah memiliki peluang untuk mengambil alih kewenangan PPAT oleh Notaris. Karena tempat kedudukan PPAT sesuai dengan tempat kedudukan kantor pertanahan kota/kabupaten.

d. Notaris harus berwenang sepanjang mengenai waktu pembuatan akta itu.

Pejabat umum - Notaris dan PPAT harus berwenang sepanjang mengenai waktu pembuatan akta itu. Notaris dalam menjalankan tugas jabatannya harus dalam keadaan aktif, artinya tidak dalam keadaan cuti atau diberhentikan 
sementara waktu. Notaris dan PPAT yang sedang cuti atau diberhentikan sementara waktu tidak mempunyai kewenangan membuat akta.

Khusus untuk Notaris dalam pasal 1 angka 2 undang-undang jabatan Notaris dikenal adanya : "pejabat sementara Notaris, yaitu seseorang yang untuk sementara waktu menjabat sebagai notaris untuk menjalankan jabatan Notaris yang meninggal dunia, diberhentikan, atau diberhentikan sementara."

Ketentuan pasal ini rancu bahwa seorang Notaris melaksanakan tugas jabatannya karena masih ada wewenang yang melekat pada dirinya. Dan karena masih ada wewenang Notaris yang bersangkutan dapat mengangkat Notaris pengganti (pasal 1 angka 3 undang-undang jabatan Notaris). Sedangkan Notaris yang meninggal dunia diberhentikan atau diberhentikan sementara waktu karena sudah tidak ada wewenang yang melekat pada dirinya sehingga tidak perlu adanya pejabat sementara Notaris. Untuk Notaris yang meninggal dunia atau diberhentikan secara protokol tersebut langsung diserahkan kepada notaris lain untuk memegang protokolnya dan untuk Notaris yang diberhentikan sementara memang yang bersangkutan sedang tidak mempunyai wewenang untuk sementara waktu, yang suatu saat dapat diangkat kembali sesuai dengan ketentuan pasal 10 ayat (2) undang-undang jabatan Notaris.

3. Akta yang dibuat oleh atau dihadapan pejabat umum.

Akta yang dibuat oleh pejabat umum disebut relaas atau akta berita acara yang berisi uraian dari pejabat umum yang dilihat dan disaksikan oleh pejabat umum sendiri atas permintaan para pihak agar tindakan atau perbuatan para pihak yang dilakukan dituangkan ke dalam bentuk akta autentik sedangkan akta yang dibuat di hadapan pejabat umum dalam praktik disebut akta pihak yang berisi uraian atau keterangan, pernyataan para pihak yang diberikan atau diceritakan di hadapan pejabat umum. Para pihak berkeinginan agar uraian atau keterangannya dituangkan dalam bentuk akta autentik.

Pembuatan akta, baik akta relaas maupun akta pihak yang menjadi dasar utama atau inti dalam pembuatan akta autentik, yaitu harus ada keinginan atau kehendak dan permintaan dari para pihak. Jika keinginan dan permintaan para pihak tidak ada, pejabat umum tidak akan membuat akta yang dimaksud. Untuk memenuhi keinginan dan permintaan para pihak pejabat umum dapat memberikan saran dengan tetap berpijak pada aturan hukum. Ketika saran pejabat umum diikuti oleh para pihak dan dituangkan dalam akta autentik, hal tersebut tetap merupakan keinginan dan permintaan para pihak, bukan saran atau pendapat pejabat umum, selain itu atau isi akta pun merupakan perbuatan para pihak, buka perbuatan atau tindakan pejabat umum.

Pengertian seperti tersebut diatas merupakan salah satu karakter yuridis dari akta autentik. Dalam hal ini tidak berarti bahwa pejabat umum sebagai pelaku dari akta tersebut, tetapi pejabat umum tetap berada di luar para pihak atau bukan pihak dalam akta tersebut. Dengan kedudukan pejabat umu seperti itu sehingga jika akta autentik dipermasalahkan, kedudukan pejabat umum tetap bukan sebagai pihak atau turut serta melakukan atau membantu para pihak dalam kualifikasi hukum pidana atau sebagai tergugat atau turut tergugat dalam perkara perdata. Penempatan pejabat umum sebagai pihak yang turut serta atau membantu para pihak dengan kualifikasi membuat atau menempatkan keterangan palsu ke dalam akta autentik atau menempatkan pejabat umum sebagai tergugat yang berkaitan dengan akta yang dibuat oleh atau dihadapan pejabat umum, maka 
hal tersebut telah menciderai akta autentik dan institusi pejabat umum yang tidak dipahami oleh aparat hukum lainnya mengenai kedudukan akta autentik dan pejabat umum di Indonesia.

Dalam tataran hukum yang benar jika suatu akta autentik dipermasalahkan oleh para pihak maka :

a. Para pihak datang kembali ke pejabat umum untuk membuat pembatalan tersebut dan jika akta yang dibatalkan sudah tidak mengikat lagi para pihak, para pihak menanggung segala akibat dari pembatalan tersebut.

b. Jika para pihak tidak sepakat bahwa akta yang bersangkutan dibatalkan, salah satu pihak dapat menggugat pihak lainnya dengan gugatan mendegradasikan akta autentik menjadi akta di bawah tangan. Setelah didegradasikan, hakim yang memeriksa gugatan dapat memberikan penafsiran tersendiri atas akta autentik yang sudah didegradasikan, apakah tetap mengikat para pihak atau dibatalkan. Hal ini bergantung pada pembuktian dan penilaian hakim.

Apabila dalam posisi yang lain, yaitu salah satu pihak merasa dirugikan dari akta yang dibuat oleh pajabat umum, pihak yang merasa dirugikan dapat mengajukan gugatan berupa tuntutan ganti rugi kepada pejabat umum yang bersangkutan dengan kewajiban penggugat, yaitu dalam gugatan harus dapat dibuktikan bahwa kerugian tersebut merupakan akibat langsung dari akta autentik tersebut. Dalam kedua posisi tersebut, penggugat harus dapat membuktikan apa saja yang dilanggar oleh pejabat umum, baik dari aspek lahiriah, aspek formal maupun aspek materiil atas akta autentik.

Berdasarkan uraian di atas maka akta pejabat umum notaris telah memenuhi syarat sebagaimana tersebut dalam pasal 1868 KUH Perdata, dengan demikian akta yang dibuat oleh atau dihadapan Notaris sebagai akta autentik yang mempunyai kekuatan pembuktian yang sempurna. Sedangkan akta pejabat umum PPAT tidak memenuhi syarat sebagaimana yang tercantum dalam pasal 1868 KUH Perdata. Dimana unsur pertama suatu akta dikatakan sebagai akta autentik apabila akta tersebut secara tersurat ditentukan oleh undang-undang. Demikian pula hal ini diberlakukan bagi akta PPAT. Akta PPAT tidak ditentukan oleh undang-undang melainkan ditentukan oleh Peraturan Pemerintah dan Peraturan Menteri Negara Agraria/Kepala BPN.

Unsur kedua suatu akta dikatakan akta autentik apabila akta tersebut dibuat oleh dan dihadapan pejabat umum yang diberikan kewenangan untuk membuat akta. Peraturan Pemerintah no.37 Tahun 1998 dan peraturan BPN no.1 Tahun 2006 mengatur bahwa PPAT sebagai pejabat umum yang diangkat dan diberhentikan oleh kepala BPN RI dan diberikan kewenangan untuk membuat akta pemindahan hak, pembebanan hak tanggungan, pembagian hak bersama dan pemberian kuasa membebaskan hak tanggungan mengenai hak atas tanah atau hak milik atas satuan rumah susun.

Unsur ketiga suatu akta dikatakan sebagai akta autentik apabila akta dibuat oleh pejabata umum dalam daerah (wilayah) kerjanya, peraturan pemerintah no.37 Tahun 1998 dan peraturan BPN No.1 tahun 2006 mengatur bahwa PPAT sebagai pejabat umum diberikan kewenangan membuat akta di dalam daerah (wilayah) kerjanya. Daerah (wilayah) kerja PPAT adalah satu wilayah kerja kantor pertanahan kabupaten atau kota.

Berdasarkan kriteria unsur-unsur akta autentik dalam Pasal 1868 KUH Perdata, maka akta yang dibuat oleh PPAT tidak memenuhi salah satu unsur sebagai akta autentik. Unsur pertama adalah bentuk akta ditetapkan oleh undang-undang tidak 
dipenuhi sebab bentuk akta PPAT ditetapkan oleh Peraturan Pemerintah dan Peraturan Menteri. Berdasarkan Pasal 7 Ayat (2) Undang-Undang No.12 Tahun 2011 tentang Pembentukan Peraturan Perundang-Undangan sesuai dengan jenis dan hierarki maka akta PPAT yang ditetapkan oleh Peraturan Pemerintah dan Peraturan Menteri adalah dibawah undang-undang. Unsur kedua dan ketiga dipenuhi yaitu PPAT sebagai pejabat umum dan PPAT mempunyai daerah (wilayah) kerja tertentu.

Dengan demikian akta peralihan hak yang dibuat oleh Pejabat Pembuat Akta Tanah (PPAT), Pejabat Pembuat Akta Ikrar Wakaf (PPAIW), Panitia Ajudikasi, Notaris yang sudah diangkat menjadi PPAT, Pejabat Kantor Lelang tidak memenuhi unsur sebagai akta autentik maka berkedudukan sebagai perjanjian biasa setingkat akta di bawah tangan. Dari segi fungsi akta PPAT hanya mempunyai pembuktian dengan kualifikasi sebagai surat di bawah tangan yang penilai pembuktiannya (jika bermasalah) diserahkan kepada hakim jika hal tersebut menjadi objek gugatan di Pengadilan Negeri. Sehubungan dengan keberadaan Pasal 15 Ayat (2) Huruf F Undang-Undang No.2 Tahun 2014 tentang Perubahan atas Undang-Undang No.30 Tahun 2004 tentang Jabatan Notaris yang menyatakan bahwa : Notaris berwenang membuat akta yang berkaitan tentang pertanahan, maka notaris bisa membuat akta yang berkaitan tentang pertanahan sepanjang undang-undang yang lain tidak mengharuskan dibuat oleh PPAT. Bidang pertanahan tidak pernah menjadi wewenang Notaris di Indonesia sejak kelahirannya.

Ketentuan Pasal 15 Ayat (2) Huruf F Undang-Undang No.2 Tahun 2014 tentang Jabatan Notaris tidak menambah wewenang Notaris di bidang pertanahan dan bukan pula pengambilalihan wewenang PPAT, masing-masing mempunyai wewenang sendiri sesuai dengan hukum yang berlaku. Jika lembaga PPAT masih tetap dipertahankan dari sistem hukum nasional segera dibuat undang-undang jabatan Pembuat Akta Tanah sehingga akta yang dibuat oleh PPAT sejajar dengan akta yang dibuat oleh Notaris sehingga legalitas akta autentik yang dibuat oleh PPAT memenuhi unsur-unsur dalam pembuatan akta autentik sebagaimana terkandung dalam Pasal 1868 KUH Perdata.

Pasal 1 Ayat (4) Peraturan Pemerintah No.37 Tahun 1998 menyebutkan : "akta PPAT adalah akta yang dibuat oleh PPAT sebagai bukti telah dilaksanakan perbuatan hukum tertentu mengenai hak atas tanah atau hak milik atas satuan rumah susun". Akta PPAT merupakan salah satu sumber utama dalam rangka pemeliharaan pendaftaran tanah di Indonesia. Setiap perjanjian yang bermaksud memindahkan hak atas tanah, memberikan suatu hak baru atas tanah, menggadaikan tanah, atau meminjam uang dengan hak atas tanah sebagai tanggungan, harus dibuktikan dengan suatu akta yang dibuat oleh dan dihadapan Pejabat Pembuat Akta Tanah.

Menurut Pasal 37 Ayat (1) Peraturan Pemerintah No.24 Tahun 1997 bahwa : "peralihan hak atas tanah dan hak milik atas satuan rumah susun melalui jual beli, tukar menukar, hibah, pemasukan data perusahaan dan perbuatan hukum pemindahan hak lainnya, kecuali pemindahan hak melalui lelang hanya dapat didaftarkan jika dibuktikan dengan akta yang dibuat oleh PPAT yang berwenang menurut ketentuan peraturan perundang-undangan yang berlaku".

PPAT sebagai pejabat umum, akta yang dibuatnya diberi kedudukan sebagai akta autentik, yaitu akta yang dibuat untuk membuktikan adanya perbuatan hukum tertentu yang mengakibatkan terjadinya peralihan hak atas tanah dan bangunan. PPAT 
mempunyai peranan besar dalam peralihan hak atas tanah karena memiliki tugas membantu kepala kantor pertanahan dalam rangka melaksanakan kegiatan pendaftaran tanah dengan membuat akta sebagai bukti telah dilakukannya perbuatan hukum tertentu mengenai hak atas tanah yang merupakan akta autentik. Sebagai akta autentik akta PPAT haruslah memenuhi tata cara pembuatan akta PPAT sebagaimana yang ditentukan oleh undang-undang dan peraturan-peraturan lainnya. Pembuatan akta yang tidak sesuai dengan tata cara pembuatan akta PPAT dapat membuat suatu akta batal demi hukum dan mengakibatkan kerugian bagi salah satu pihak dalam akta tersebut.

Pejabat Pembuat Akta Tanah mempunyai peran yang penting dalam pendaftaran tanah, yaitu membantu Kepala Kantor Pertanahan Kabupaten/Kota untuk melaksanakan kegiatan-kegiatan tertentu dalam pendaftaran tanah. Kata "dibantu" dalam Pasal 6 Ayat (2) PP No.24 Tahun 1997 disini tidak berarti bahwa PPAT merupakan bawahan dari kantor pertanahan kabupaten atau kota yang dapat diperintah olehnya, akan tetapi PPAT mempunyai kemandirian dalam melaksanakan tugas dan wewenangnya.

Tugas pokok PPAT dalam membantu pelaksanaan pendaftaran tanah oleh Kepala Kantor Pertanahan Kabupaten/Kota ditetapkan dalam Pasal 2 PP No.37 Tahun 1998, yaitu : melaksanakan sebagian pendaftaran tanah dengan membuat akta sebagai bukti telah dilakukan perbuatan hukum tertentu mengenai hak atas tanah atau hak milik atas satuan rumah susun yang akan dijadikan dasar bagi pendaftaran perubahan data pendaftaran tanah yang diakibatkan perbuatan hukum tadi. Adapun perbuatan hukum yang dimaksud adalah : jual beli, tukar menukar, hibah, pemasukan kedalam perusahaan (inbreng), pembagian hak bersama, pemberian hak guna bangunan/hak pakai atas tanah hak milik, pemberian hak tanggungan dan pemberian hak kuasa membebankan hak tanggungan.

Pejabat Pembuat Akta Tanah dan Pejabat Pembuat Akta Tanah Sementara hanya berwenang membuat akta autentik terhadap perbuatan mengenai hak atas tanah atau hak milik atas satuan rumah susun yang terletak dalam daerah kerjanya. Daerah kerja PPAT adalah satu wilayah kerja kantor pertanahan kabupaten/kota, sedangkan daerah kerja PPAT Sementara meliputi wilayah kerja sebagai pejabat pemerintah yang menjadi dasar penunjukan.

Dalam Pasal 1 Angka 4 Undang-Undang No.4 Tahun 1996 menyatakan : "Pejabat Pembuat Akta Tanah adalah pejabat umum yang diberi wewenang untuk membuat akta pemindahan hak atas tanah, akta pembebanan hak tanggungan menurut perundang-undangan yang berlaku". Istilah pejabat umum bagi pejabat pembuat akta tanah baru ada pada Undang-Undang No.4 Tahun 1996, namun dalam undang-undang ini maupun pada peraturan perundang-undangan yang lain tidak memberikan pengertian apa yang dimaksud pejabat umum.

Menurut Boedi Harsono, yang dimaksud pejabat umum adalah seorang yang diangkat oleh pemerintah dengan tugas kewenangan memberikan pelayanan di bidang tertentu. Sejalan dengan Boedi Harsono, Sri Winarsih menyatakan bahwa pengertian pejabat umum mempunyai karakter yuridis, yaitu selalu dalam rangka hukum publik. Sifat publiknya dapat dilihat dari pengangkatan, pemberhentian, dan kewenangan pejabat pembuat akta tanah. Pejabat Pembuat Akta Tanah diangkat dan diberhentikan oleh Kepala Badan Pertanahan Nasional Republik Indonesia, tugasnya adalah membantu kepala kantor pertanahan kabupaten/kota dalam melaksanakan sebagian kegiatan pendaftaran tanah, dan kewenangannya adalah membuat akta atas perbuatan hukum tertentu mengenai hak atas tanah atau hak milik atas satuan rumah susun.

Menurut ketentuan peraturan perundang-undangan yang berlaku, Pasal 3 Ayat (1) PP No.37 Tahun 1998 jo. Pasal 3 Ayat (1) Peraturan Kepala BPN No.1 Tahun 2006 
menegaskan bahwa akta yang dibuat oleh Pejabat Pembuat Akta Tanah adalah akta autentik. Pejabat Pembuat Akta Tanah yang berwenang membuat akta jual beli hak atas tanah atau hak milik atas satuan rumah susun berdasarkan Pasal 1 Angka 1 PP No.37 Tahun 1998 tentang peraturan jabatan pejabat pembuat akta tanah adalah Pejabat Pembuat Akta Tanah sebagai pejabat umum yang diberikan kewenangan untuk membuat akta-akta autentik mengenai perbuatan-perbuatan hukum tertentu mengenai hak atas tanah atau hak milik atas satuan rumah susun. Disamping itu menurut Pasal 1 Angka 2 PP No.37 Tahun 1998 yang berwenang membuat akta jual beli adalah Pejabat Pembuat Akta Tanah Sementara yang ditunjuk karena jabatannya (Kepala Kecamatan). Dengan telah dibuatnya akta jual beli oleh Pejabat Pembuat Akta Tanah maka pada saat itu telah terjadi pemindahan hak atas tanah.

Menurut Pasal 1 Angka 4 PP No.37 Tahun 1998 jo. Pasal 1 Angka 4 Peraturan Kepala BPN No.1 Tahun 2006 akta PPAT adalah akta yang dibuat oleh PPAT sebagai bukti dilaksanakannya perbuatan hukum tertentu mengenai hak atas tanah atau hak milik atas satuan rumah susun.

Menurut Pasal 39 Ayat (1) PP No.24 Tahun 1997 PPAT menolak membuat akta jual beli jika :

7. Mengait bidang tanah yang sudah terdaftar kepadanya tidak disampaikan sertipikat asli hak atas tanah yang bersangkutan atau sertipikat yang diserahkan tidak sesuai dengan daftar-daftar yang ada di kantor pertanahan kabupaten/kota.

8. Salah satu/para pihak yang akan melakukan jual beli atau saksinya tidak berhak atau memenuhi syarat untuk bertindak dalam jual beli.

9. Salah satu atau para pihak bertindak atas dasar surat kuasa mutlak yang pada hakikatnya berisikan perbuatan hukum pemindahan hak.

10. Untuk jual beli yang akan dilakukan belum diperoleh izin pejabat atau instansi yang berwenang.

11. Objek jual beli yang sedang dalam sengketa mengenai data fisik dan data yuridis.

12. Tidak dipenuhi syarat lain atau dilanggar larangan yang ditentukan dalam peraturan perundangan yang berlaku.

Penolakan untuk melakukan jual beli tersebut diberitahukan oleh PPAT secara tertulis kepada pihak-pihak yang bersangkutan beserta alasannya.

Menurut Pasal 45 Ayat (2) PP No.24 Tahun 1997 Kepala Kantor Pertanahan menolak untuk melakukan pendaftaran peralihan atau pembebanan hak jika salah satu syarat tidak dipenuhi diantaranya syarat tersebut yaitu : perbuatan hukum sebagaimana dimaksud dalam Pasal 37 Ayat (1) dalam peraturan ini tidak dibuktikan dengan akta PPAT atau kutipan risalah lelang sebagaimana yang dimaksud dalam Pasal 41, kecuali dalam keadaan tertentu sebagaimana dimaksud Pasal 37 Ayat (2) dalam peraturan ini.

Pasal 3 Ayat (1) PP No 31 Tahun 1998 jo. Pasal 3 Ayat (1) Peraturan Kepala Badan Pertanahan Nasional No.1 Tahun 2006 menegaskan bahwa akta yang dibuat oleh PPAT adalah akta autentik. Dalam kedua peraturan ini tidak dijelaskan apa yang dimaksud dengan akta autentik. Akta autentik menurut Pasal 1868 KUH Perdata, adalah suatu akta di dalam bentuk yang ditentukan oleh undang-undang, dibuat oleh dan dihadapan pegawai-pegawai umum yang berkuasa untuk itu dimana akta dibuatnya.

Suatu akta dinyatakan sebagai akta autentik apabila memenuhi unsur-unsur yang bersifat komulatif sebagaimana ditentukan oleh Pasal 1868 KUH Perdata, yaitu :

4. Bentuk akta ditentukan oleh undang-undang

5. Akta dibuat oleh dan dihadapan pegawai-pegawai umum yang berkuasa

6. Akta dibuat dimana akta dibuatnya 
Pendapat yang sama tentang unsur-unsur akta autentik dikemukakan oleh Wawan Setiawan, yaitu :

4. Bentuk akta harus ditentukan oleh undang-undang artinya tidak boleh ditentukan oleh perangkat peraturan perundang-undangan di bawah undang-undang

5. Dibuat oleh dan dihadapan pejabat umum

6. Akta tersebut dibuat oleh atau dihadapan pejabat umum dalam wilayah jabatan sesuai dengan kewenangannya

Berdasarkan ketentuan Pasal 1868 KUH Perdata dapat disimpulkan bahwa, suatu akta dinyatakan sebagai akta autentik apabila mempunyai 3 unsur yang bersifat komulatif, yaitu :

4. Bentuk akta ditentukan oleh UU

5. Akta dibuat oleh dan dihadapan pejabat umum yang diberi kewenangan untuk membuat akta

6. Akta dibuat oleh pejabat umum dalam daerah (wilayah) kerjanya Akta PPAT tidak ditentukan oleh undang-undang melainkan ditentukan oleh PP dan Peraturan Menteri Negara Agraria/ Kepala BPN, yaitu :

4. Pasal 38 Ayat (2) PP No. 24 Tahun 1997 menyatakan bahwa bentuk, isi dan cara pembuatan akta-akta PPAT diaturan oleh Peraturan Menteri Negara Agraria. Kepala BPN

5. Pasal 21 PP No. 37 Tahun 1998 menyatakan bahwa akta PPAT dibuat dengan bentuk yang ditetapkan oleh Menteri Negara Agraria/ Kepala BPN

6. Pasal 95 dan Pasal 96 Peraturan Menteri Negara Agraria/ Kepala BPN No.3 Tahun 1997 menetapkan bahwa macam dan bentuk akta yang dibuat oleh PPAT

Berdasarkan ketiga peraturan ini menunjukkan bahwa akta PPAT bentuknya tidak ditentukan oleh undang-undang melainkan ditetapkan oleh PP dan Peraturan Menteri, meskipun akta PPAT tersebut bentuknya baku dan dibuat oleh PPAT sebagai pejabat umum. Untuk lebih konkritnya dalam menelaah kedudukan hukum akta autentik yang dibuat oleh PPAT penulis komparasikan dengan akta autentik yang dibuat oleh notaris yang telah dibuat berdasarkan kententuan Undang-Undang No.2 Tahun 20014 tentang Perubahan atas Undang-Undang No.30 Tahun 2004 tentang Jabatan Notaris serta Undang-Undang No.12 Tahun 2011 tentang Pembentukan Peraturan PerundangUndangan.

Adapun syarat-syarat yang harus dipenuhi untuk dapat dikategorikan sebagai akta autentik dalam komparasi ini, diuraikan sebagai berikut :

3. Akta itu harus dibuat dalam bentuk yang ditentukan oleh undang-undang

Akta yang dibuat oleh atau dihadapan pejabat umum dalam bentuk yang sudah ditentukan undang-undang harus diartikan sebagaimana yang tersebut dalam Undang-Undang No.12 Tahun 2011 tentang Pembentukan Peraturan Perundang-Undangan, Pasal 1 Angka 2 yang menegaskan bahwa : "peraturan perundang-undangan adalah peraturan tertulis yang memuat norma hukum yang mengikat secara umum dan dibentuk atau ditetapkan oleh lembaga negara atau pejabat yang berwenang melalui prosedur yang ditetapkan dalam peraturan perundang-undangan “.

Dalam Pasal 1 angka 3 undang-undang ini menegaskan bahwa : "undangundang adalah peraturan perundang-undangan yang dibentuk oleh DPR dengan persetujuan bersama Presiden".

Berdasarkan Pasal 7 Ayat (1) dan (2) Undang-Undang No.12 Tahun 2011 tentang Pembentukan Peraturan Perundang-Undangan dinyatakan bahwa jenis hierarki peraturan perundang-undangan terdiri atas : 
8. Undang-Undang Dasar Negara Republik Indonesia Tahun 1945

9. Ketetapan MPR

10. Undang-Undang/Peraturan Pemerintah Pengganti Undang-Undang

11. Peraturan Pemerintah

12. Peraturan Presiden

13. Peraturan Daerah Provinsi; dan

14. Peraturan Daerah Kabupaten/Kota

Berdasarkan ketentuan Pasal 7 Ayat (2) undang-undang ini kekuatan hukum peraturan perundang-undangan sesuai dengan hierarki yang telah ditetapkan sebagaimana tertuang dalam Pasal 7 Ayat (1) undang-undang ini.

Pengaturan pertama kali notaris Indonesia berdasarkan instruktie foor de notarissen residerende in nederlands indie dengan stbl.No 11, tanggal 7 Maret 1822, kemudian dengan reglement op het notaris ambt in Indonesie (stbl. 1860 : 3), dan reglement ini berasal dari wet op het notarisambt (1842). Selanjutnya reglement tersebut diterjemahkan menjadi peraturan jabatan notaris. Meskipun notaris di Indonesia diatur dalam bentuk reglement, hal tersebut tidak dipermasalahkan karena sejak lembaga Notaris lahir di Indonesia, pengaturannya tidak lebih dari bentuk reglement dan secara kelembagaan dengan UndangUndang No.33 Tahun 1954 yang tidak mengatur mengenai bentuk akta. Setelah lahirnya undang-undang jabatan notaris, keberadaan akta notaris mendapat pengukuhan karena bentuknya ditentukan oleh undang-undang, dalam hal ini dalam Pasal 38 undang-undang jabatan Notaris. Akta PPAT sampai dengan saat ini belum diatur keberadaannya dalam bentuk undang-undang tetapi dalam PP atau Peraturan Menteri.

4. Pejabat umum oleh - atau dihadapan siapa akta itu dibuat, harus memenuhi wewenang untuk membuat akta itu.

Kewenangan Notaris dan PPAT meliputi 4 hal, yaitu :

e. Notaris harus berwenang sepanjang menyangkut akta yang harus dibuat itu.

Wewenang Notaris dan PPAT dalam pembuatan akta autentik sepanjang tidak dikecualikan kepada atau pejabat lain atau notaris juga berwenang membuatnya. Disamping dapat dibuat oleh pihak atau pejabat lain, juga mengandung makna bahwa wewenang notaris dalam membuat akta autentik mempunyai wewenang yang umum, sedangkan pihak lainnya mempunyai wewenang yang terbatas. Misalnya, PPAT mempunyai wewenang terbatas, yaitu hanya membuat 8 jenis akta.

f. Notaris harus berwenang sepanjang mengenai orang untuk kepentingan siapa akta itu dibuat.

Pejabat umum-Notaris dan PPAT berwenang sepanjang mengenai orang untuk kepentingan siapa akta itu dibuat. Mengenai orang dan untuk siapa akta dibuat harus ada keterkaitan yang jelas. Misalnya, jika akan dibuat akta pengikatan jual beli yang diikuti dengan akta kuasa untuk menjual, pihak yang akan menjual mempunyai wewenang untuk menjualnya kepada siapapun. Untuk mengetahui ada keterkaitan semacam itu, sudah tentu notaris akan melihat (asli surat) dan meminta fotokopi atas identitas dan bukti kepemilikannya. Salah satu tanda bukti yang sering diminta oleh notaris dalam pembuatan akta notaris, yaitu kartu tanda tertentu (KTP) dan sertipikat tanah sebagai bukti kepemilikannya. Ada kemungkinan orang yang namanya tersebut dalam KTP dan sertipikat bukan orang yang sama, artinya pemilik 
sertipikat bukan orang yang sesuai dengan KTP. Hal ini bisa terjadi (di Indonesia) karena banyak kesamaan nama dan mudahnya membuat KTP serta dalam sertipikat hanya tertulis nama pemegang hak, tanpa ada penyebutan identitas lain. Dalam kejadian seperti ini, bagi Notaris tidak menimbulkan permasalahan apapun tetapi dari segi lain notaris oleh pihak yang berwajib (kepolisian/penyidik) dianggap memberikan kemudahan untuk terjadinya suatu tindak pidana. Berkaitan dengan identitas diri penghadap dan bukti kepemilikannya yang di bawa dan aslinya diperlihatkan ternyata palsu, maka hal ini bukan tanggung jawab notaris melainkan tanggung jawab tersebut diserahkan para pihak yang menghadap.

g. Pejabat umum harus berwenang sepanjang mengenai tempat dimana akta itu dibuat.

Pejabat umum - Notaris dan PPAT harus berwenang sepanjang mengenai tempat dimana akta itu dibuat. Baik notaris maupun PPAT mempunyai tempat kedudukan dan wilayah kerjanya masing-masing. Misalnya untuk notaris sebagaimana tercantum dalam pasal 18 ayat (1) undang-undang jabatan Notaris menentukan bahwa Notaris harus berkedudukan di daerah kabupaten atau kota. Setiap Notaris sesuai dengan keinginannya mempunyai tempat kedudukan dan wilayah kerjanya masing-masing. Misalnya, untuk Notaris sebagaimana tercantum dalam pasal 18 ayat (1) undang-undang jabatan Notaris menentukan bahwa notaris harus berkedudukan di daerah kabupaten atau kota. Setiap Notaris sesuai dengan keinginannya mempunyai tempat kedudukan dan berkantor di daerah kabupaten/ kota (pasal 19 ayat (1) undang-undang jabatan Notaris). Notaris mempunyai wilayah jabatan meliputi seluruh wilayah propinsi dari tempat kedudukannya (pasal 19 ayat (2) undang-undang jabatan Notaris). Pengertian pasal-pasal tersebut bahwa Notaris dalam menjalankan tugas jabatannya tidak hanya harus berada di tempat kedudukannya karena notaris mempunyai wilayah seluruh propinsi misalnya, Notaris yang berkedudukan di kota Surabaya, maka dapat membuat akta di kabupaten atau kota lain dalam wilayah propinsi jawa timur. Hal ini dapat dijalankan dengan ketentuan :

4. Ketika Notaris menjalan tugas jabatannya (membuat akta) diluar tempat kedudukannya Notaris tersebut harus berada di tempat akta akan dibuat. Sebagi contoh, notaris yang berkedudukan di Surabaya akan membuat akta di Mojokerto, maka Notaris yang bersangkutan harus membuat dan menyelesaikan akta tersebut di Mojokerto.

5. Pada akhir akta harus disebutkan tempat (kota atau kabupaten) pembuatan dan penyelesaian akta.

6. Menjalankan tugas jabatan di luar tempat kedudukan Notaris dalam wilayah jabatan 1 provinsi tidak merupakan suatu keteraturan yang tidak terus menerus (pasal 19 ayat (2) undang-undang jabatan Notaris)

Ketentuan tersebut dalam praktik memberikan peluang pada Notaris untuk menambah dan melintasi batas tempat kedudukan dalam pembuatan akta. Hal tersebut bukan merupakan suatu hal yang dilarang untuk dilakukan karena yang dilarang adalah menjalankan tugas jabatannya diluar wilayah jabatannya atau diluar provinsi (pasal 17 huruf a undang-undang jabatan Notaris). Akan tetapi untuk saling menghormati antar Notaris di kabupaten atau kota lain lebih baik hal seperti itu tidak dilakukan. Berikan penjelasan kepada para pihak dengan membuat akta yang di inginkan utk datang menghadap Notaris di kabupaten atau 
kota yang bersangkutan. Dalam keadaan tertentu dapat saja dilakukan jika di kabupaten atau kota tersebut tidak ada Notaris.

Adanya ketentuan tersebut bagi Notaris yang mempunyai tempat kedudukan di kota atau kabupaten dan wilayah kerja provinsi, sebenarnya telah memiliki peluang untuk mengambil alih kewenangan PPAT oleh Notaris. Karena tempat kedudukan PPAT sesuai dengan tempat kedudukan kantor pertanahan kota/kabupaten.

h. Notaris harus berwenang sepanjang mengenai waktu pembuatan akta itu.

Pejabat umum - Notaris dan PPAT harus berwenang sepanjang mengenai waktu pembuatan akta itu. Notaris dalam menjalankan tugas jabatannya harus dalam keadaan aktif, artinya tidak dalam keadaan cuti atau diberhentikan sementara waktu. Notaris dan PPAT yang sedang cuti atau diberhentikan sementara waktu tidak mempunyai kewenangan membuat akta.

Khusus untuk Notaris dalam pasal 1 angka 2 undang-undang jabatan Notaris dikenal adanya : "pejabat sementara Notaris, yaitu seseorang yang untuk sementara waktu menjabat sebagai notaris untuk menjalankan jabatan Notaris yang meninggal dunia, diberhentikan, atau diberhentikan sementara."

Ketentuan pasal ini rancu bahwa seorang Notaris melaksanakan tugas jabatannya karena masih ada wewenang yang melekat pada dirinya. Dan karena masih ada wewenang Notaris yang bersangkutan dapat mengangkat Notaris pengganti (pasal 1 angka 3 undang-undang jabatan Notaris). Sedangkan Notaris yang meninggal dunia diberhentikan atau diberhentikan sementara waktu karena sudah tidak ada wewenang yang melekat pada dirinya sehingga tidak perlu adanya pejabat sementara Notaris. Untuk Notaris yang meninggal dunia atau diberhentikan secara protokol tersebut langsung diserahkan kepada notaris lain untuk memegang protokolnya dan untuk Notaris yang diberhentikan sementara memang yang bersangkutan sedang tidak mempunyai wewenang untuk sementara waktu, yang suatu saat dapat diangkat kembali sesuai dengan ketentuan pasal 10 ayat (2) undang-undang jabatan Notaris.

4. Akta yang dibuat oleh atau dihadapan pejabat umum.

Akta yang dibuat oleh pejabat umum disebut relaas atau akta berita acara yang berisi uraian dari pejabat umum yang dilihat dan disaksikan oleh pejabat umum sendiri atas permintaan para pihak agar tindakan atau perbuatan para pihak yang dilakukan dituangkan ke dalam bentuk akta autentik sedangkan akta yang dibuat di hadapan pejabat umum dalam praktik disebut akta pihak yang berisi uraian atau keterangan, pernyataan para pihak yang diberikan atau diceritakan di hadapan pejabat umum. Para pihak berkeinginan agar uraian atau keterangannya dituangkan dalam bentuk akta autentik.

Pembuatan akta, baik akta relaas maupun akta pihak yang menjadi dasar utama atau inti dalam pembuatan akta autentik, yaitu harus ada keinginan atau kehendak dan permintaan dari para pihak. Jika keinginan dan permintaan para pihak tidak ada, pejabat umum tidak akan membuat akta yang dimaksud. Untuk memenuhi keinginan dan permintaan para pihak pejabat umum dapat memberikan saran dengan tetap berpijak pada aturan hukum. Ketika saran pejabat umum diikuti oleh para pihak dan dituangkan dalam akta autentik, hal tersebut tetap merupakan keinginan dan permintaan para pihak, bukan saran atau pendapat pejabat umum, selain itu atau isi akta pun merupakan perbuatan para pihak, buka perbuatan atau tindakan pejabat umum. 
Pengertian seperti tersebut diatas merupakan salah satu karakter yuridis dari akta autentik. Dalam hal ini tidak berarti bahwa pejabat umum sebagai pelaku dari akta tersebut, tetapi pejabat umum tetap berada di luar para pihak atau bukan pihak dalam akta tersebut. Dengan kedudukan pejabat umu seperti itu sehingga jika akta autentik dipermasalahkan, kedudukan pejabat umum tetap bukan sebagai pihak atau turut serta melakukan atau membantu para pihak dalam kualifikasi hukum pidana atau sebagai tergugat atau turut tergugat dalam perkara perdata. Penempatan pejabat umum sebagai pihak yang turut serta atau membantu para pihak dengan kualifikasi membuat atau menempatkan keterangan palsu ke dalam akta autentik atau menempatkan pejabat umum sebagai tergugat yang berkaitan dengan akta yang dibuat oleh atau dihadapan pejabat umum, maka hal tersebut telah menciderai akta autentik dan institusi pejabat umum yang tidak dipahami oleh aparat hukum lainnya mengenai kedudukan akta autentik dan pejabat umum di Indonesia.

Dalam tataran hukum yang benar jika suatu akta autentik dipermasalahkan oleh para pihak maka :

c. Para pihak datang kembali ke pejabat umum untuk membuat pembatalan tersebut dan jika akta yang dibatalkan sudah tidak mengikat lagi para pihak, para pihak menanggung segala akibat dari pembatalan tersebut.

d. Jika para pihak tidak sepakat bahwa akta yang bersangkutan dibatalkan, salah satu pihak dapat menggugat pihak lainnya dengan gugatan mendegradasikan akta autentik menjadi akta di bawah tangan. Setelah didegradasikan, hakim yang memeriksa gugatan dapat memberikan penafsiran tersendiri atas akta autentik yang sudah didegradasikan, apakah tetap mengikat para pihak atau dibatalkan. Hal ini bergantung pada pembuktian dan penilaian hakim.

Apabila dalam posisi yang lain, yaitu salah satu pihak merasa dirugikan dari akta yang dibuat oleh pajabat umum, pihak yang merasa dirugikan dapat mengajukan gugatan berupa tuntutan ganti rugi kepada pejabat umum yang bersangkutan dengan kewajiban penggugat, yaitu dalam gugatan harus dapat dibuktikan bahwa kerugian tersebut merupakan akibat langsung dari akta autentik tersebut. Dalam kedua posisi tersebut, penggugat harus dapat membuktikan apa saja yang dilanggar oleh pejabat umum, baik dari aspek lahiriah, aspek formal maupun aspek materiil atas akta autentik.

Berdasarkan uraian di atas maka akta pejabat umum notaris telah memenuhi syarat sebagaimana tersebut dalam pasal 1868 KUH Perdata, dengan demikian akta yang dibuat oleh atau dihadapan Notaris sebagai akta autentik yang mempunyai kekuatan pembuktian yang sempurna. Sedangkan akta pejabat umum PPAT tidak memenuhi syarat sebagaimana yang tercantum dalam pasal 1868 KUH Perdata. Dimana unsur pertama suatu akta dikatakan sebagai akta autentik apabila akta tersebut secara tersurat ditentukan oleh undang-undang. Demikian pula hal ini diberlakukan bagi akta PPAT. Akta PPAT tidak ditentukan oleh undang-undang melainkan ditentukan oleh Peraturan Pemerintah dan Peraturan Menteri Negara Agraria/Kepala BPN.

Unsur kedua suatu akta dikatakan akta autentik apabila akta tersebut dibuat oleh dan dihadapan pejabat umum yang diberikan kewenangan untuk membuat akta. Peraturan Pemerintah no.37 Tahun 1998 dan peraturan BPN no.1 Tahun 2006 mengatur bahwa PPAT sebagai pejabat umum yang diangkat dan diberhentikan oleh kepala BPN RI dan diberikan kewenangan untuk membuat akta pemindahan hak, pembebanan hak tanggungan, pembagian hak bersama dan pemberian kuasa 
membebaskan hak tanggungan mengenai hak atas tanah atau hak milik atas satuan rumah susun.

Unsur ketiga suatu akta dikatakan sebagai akta autentik apabila akta dibuat oleh pejabata umum dalam daerah (wilayah) kerjanya, peraturan pemerintah no.37 Tahun 1998 dan peraturan BPN No.1 tahun 2006 mengatur bahwa PPAT sebagai pejabat umum diberikan kewenangan membuat akta di dalam daerah (wilayah) kerjanya. Daerah (wilayah) kerja PPAT adalah satu wilayah kerja kantor pertanahan kabupaten atau kota.

Berdasarkan kriteria unsur-unsur akta autentik dalam Pasal 1868 KUH Perdata, maka akta yang dibuat oleh PPAT tidak memenuhi salah satu unsur sebagai akta autentik. Unsur pertama adalah bentuk akta ditetapkan oleh undang-undang tidak dipenuhi sebab bentuk akta PPAT ditetapkan oleh Peraturan Pemerintah dan Peraturan Menteri. Berdasarkan Pasal 7 Ayat (2) Undang-Undang No.12 Tahun 2011 tentang Pembentukan Peraturan Perundang-Undangan sesuai dengan jenis dan hierarki maka akta PPAT yang ditetapkan oleh Peraturan Pemerintah dan Peraturan Menteri adalah dibawah undang-undang. Unsur kedua dan ketiga dipenuhi yaitu PPAT sebagai pejabat umum dan PPAT mempunyai daerah (wilayah) kerja tertentu.

Dengan demikian akta peralihan hak yang dibuat oleh Pejabat Pembuat Akta Tanah (PPAT), Pejabat Pembuat Akta Ikrar Wakaf (PPAIW), Panitia Ajudikasi, Notaris yang sudah diangkat menjadi PPAT, Pejabat Kantor Lelang tidak memenuhi unsur sebagai akta autentik maka berkedudukan sebagai perjanjian biasa setingkat akta di bawah tangan. Dari segi fungsi akta PPAT hanya mempunyai pembuktian dengan kualifikasi sebagai surat di bawah tangan yang penilai pembuktiannya (jika bermasalah) diserahkan kepada hakim jika hal tersebut menjadi objek gugatan di Pengadilan Negeri. Sehubungan dengan keberadaan Pasal 15 Ayat (2) Huruf F Undang-Undang No.2 Tahun 2014 tentang Perubahan atas Undang-Undang No.30 Tahun 2004 tentang Jabatan Notaris yang menyatakan bahwa : Notaris berwenang membuat akta yang berkaitan tentang pertanahan, maka notaris bisa membuat akta yang berkaitan tentang pertanahan sepanjang undang-undang yang lain tidak mengharuskan dibuat oleh PPAT. Bidang pertanahan tidak pernah menjadi wewenang Notaris di Indonesia sejak kelahirannya.

Ketentuan Pasal 15 Ayat (2) Huruf F Undang-Undang No.2 Tahun 2014 tentang Jabatan Notaris tidak menambah wewenang Notaris di bidang pertanahan dan bukan pula pengambilalihan wewenang PPAT, masing-masing mempunyai wewenang sendiri sesuai dengan hukum yang berlaku. Jika lembaga PPAT masih tetap dipertahankan dari sistem hukum nasional segera dibuat undang-undang jabatan Pembuat Akta Tanah sehingga akta yang dibuat oleh PPAT sejajar dengan akta yang dibuat oleh Notaris sehingga legalitas akta autentik yang dibuat oleh PPAT memenuhi unsur-unsur dalam pembuatan akta autentik sebagaimana terkandung dalam Pasal 1868 KUH Perdata.

\section{KESIMPULAN}

Pejabat Pembuat Akta Tanah adalah pejabat umum yang diberi kewenangan untuk membuat akta-akta autentik mengenai perbuatan hukum tertentu mengenai hak atas tanah. Pejabat yang diberi wewenang untuk membuat akta peralihan hak atas tanah adalah PPAT, PPAIW, Panitia Ajudikasi, Notaris yang sudah diangkat menjadi PPAT, 
dan Pejabat Kantor Lelang. Akta yang dibuat oleh PPAT dalam peralihan hak atas tanah mempunyai fungsi yaitu :

1. Sebagai bukti telah diadakan perbuatan hukum tertentu mengenai hak atas tanah.

2. Dijadikan dasar bagi pendaftaran perubahan data pendaftaran tanah dikantor pertanahan kabupaten/kota.

Akta PPAT bentuk aktanya ditentukan oleh Peraturan Pemerintah dan Peraturan Menteri Negara Agraria/Kepala BPN, yaitu :

1. Pasal 38 Ayat (2) PP No.24 Tahun 1997 menyatakan; bahwa bentuk, isi dan cara pembuatan akta-akta PPAT diatur Menteri Negara Agraria/Kepala Badan Pertanahan Nasional.

2. Pasal 21 PP No.37 Tahun 1998 menyatakn; bahwa akta PPAT dibuat dengan bentuk yang ditetapkan oleh Menteri Negara Agraria/Kepala Badan Pertanahan Nasional.

3. Pasl 95 dan Pasal 96 Peraturan Menteri Negara Agraria/ Kepala Badan Pertanahan Nasional No.3 Tahun 1997 menetapkan macam dan bentuk akta yang dibuat oleh PPAT.

Suatu akta dinyatakan sebagai akta autentik apabila memenuhi unsur-unsur kumulatif dalam Pasal 1868 KUH Perdata, yaitu :

1. Bentuk akta harus ditentukan oleh undang-undang artinya tidak boleh ditentukan oleh perangkat peraturan perundang-undangan di bawah undang-undang.

2. Dibuat oleh dan dihadapan pejabat umum.

3. Akta tersebut dibuat oleh atau dihadapan pejabat umum dalam wilayah jabatannya sesuai kewenangannya.

Akta autentik yang dibuat oleh Pejabat Pembuat Akta Tanah (PPAT) tidak memenuhi salah satu unsur komulatif Pasal 1868 KUH Perdata karena bentuk akta PPAT ditetapkan oleh Peraturan Pemerintah dan Peraturan Menteri seharusnya secara tersurat bentuknya ditetapkan oleh undang-undang. Unsur kedua dan ketiga dipenuhi yaitu PPAT sebagai pejabat umum dan PPAT mempunyai daerah (wilayah) kerja tertentu.

Berdasarkan Pasal 7 Ayat (1) dan (2) Undang-Undang No.12 Tahun 2011 tentang Peraturan Perundang-Undangan akta autentik yang dibuat oleh PPAT kekuatan hukumnya berada di bawah undang-undang karena bentuk isi dan cara pembuatannya ditentukan Peraturan Pemerintah dan Peraturan Menteri Negara Agraria. Dengan demikian akta yang dibuat oleh PPAT berkedudukan sebagai perjanjian biasa setingkat akta di bawah tangan dan dari segi fungsi akta PPAT hanya mempunyai pembuktian dengan kualifikasi sebagai surat di bawah tangan yang penilaian pembuktiannya diserahkan kepada hakim jika menjadi objek gugatan di Pengadilan Negeri.

Akta pertanahan yang dibuat notaris berdasarkan Pasal 15 Ayat (2) Huruf F Undang-Undang No.2 Tahun 2014 tentang Jabatan Notaris akan berlaku sebagai akta autentik sepanjang undang-undang yang lain tidak mengharuskan akta pertanahan itu dibuat oleh PPAT. Sejak kelahiran lembaga notaris di Indonesia bidang pertanahan tidak pernah menjadi wewenang notaris.

\section{DAFTAR PUSTAKA}

Boedi Harsono. 2007. PPAT Sejarah Tugas dan Kewenangannya. Jakarta : Majalah Renvoi No. 8.44.IV 
R. Soebekti dan R. Tjitro Sudibyo. 1985. Kitab Undang-Undang Hukum Perdata. Jakarta : Pradnya Paramita.

R. Soebekti dan R. Tjitrosudibio. 1985. Kitab Undang-Undang Hukum Perdata Bugerlijk Wetboek. Jakarta : Pradnya Paramita

Sri Winarsi. 2002. Pengaturan Notaris dan Pejabat Pembuat Akta Tanah sebagai Pejabat Umum. Surabaya : Majalah Yuridika Vol.17 No.2

Wawan Setiawan. 1966. Kedudukan dan Keberadaan Pejabat Umum serta PPAT Dibandingkan dengan Kedudukan Pejabat Tata Usaha Negara Menurut Sistem Hukum Nasional. Surabaya: Makalah, 1 Juni 1966

Undang-Undang No.5 Tahun 1960 tentang Peraturan dasar pokok-pokok agraria

Undang-Undang No.4 Tahun 1992 tentang Perumahan dan Pemukiman

Undang-Undang No.4 Tahun 1996 tentang Hak Tanggungan atas Tanah beserta bendabenda yang berkaitan dengan tanah

Undang-Undang No.12 Tahun 2011 tentang Pembentukan Peraturan PerundangUndangan

Undang-Undang No.2 Tahun 2014 tentang Perubahan atas Undang-Undang No.30 tahun 2004 tentang Jabatan Notaris

Peraturan Pemerintah No.24 Tahun 1997 tentang Pendaftaran Tanah

Peraturan Menteri Negara agraria/Kepala BPN No.3 Tahun 1997 tentang ketentuan pelaksanaan peraturan pemerintah no.24 tahun 1997 tentang pendaftaran tanah

Peraturan Kepala BPN No.1 Tahun 2006 tentang ketentuan pelaksanaan PP No.37 Tahun 1998 tentang peraturan jabatan PPAT 